ISBN 978-81-943403-5-5

16th ROME International Conference on Advances in Agricultural, Biological and Environmental

Sciences (RAABE-20)

Rome (Italy) Feb. 3-5, 2020

\title{
Conceptual Framework of Agricultural Development in developing Oil Rich Countries (Case of Libya)
}

\author{
Masauda Abuarosha ${ }^{1}$, and Abdalsalam Mohamed ${ }^{2}$ \\ ${ }^{1}$ Omar Almokhtar University, Faculty of Agriculture, Libya \\ ${ }^{2}$ Agricultural Research Center, Libya
}

\begin{abstract}
The heavy dependence on oil revenues has negatively affected the development of the agriculture sector, as the continual flow of oil revenues has allowed the government to fund the sector without paying due attention to the economic efficiency or economic returns of most of the agricultural projects which hampered by widespread corruption and weak control by the public sector. The money surplus in the national budget, which was generated by the continual flow of oil revenues, has also allowed the government to easily access the international market, which has made it much easier for the country to import food than to produce it, Also the availability of high revenues from oil allowed the government to persist with self-sufficiency ideology as well as other related political ideologies regardless of their validity or efficiency. Whilst the economic system is fundamentally based on socialist theories and a planned economy, with the public sector taking precedence over the private sector, there is evidence that political leadership's beliefs strongly affected the stability of the economic system and the government institutions.
\end{abstract}

Keywords: Agriculture, development, oil rich country.

\section{Introduction}

The natural resources promote economic growth and development, because it expands the production possibilities of an economy. However economic development is much broader than economic growth; although economic growth is a precondition for economic development. Grabowski et al. (2007, p 6) stated that "countries which are typically poor are also typically less developed, though a rich country does not necessarily have to be a developed country", adding that "some of the oil rich African and Middle East countries have experienced large increases in per capita GDP, yet they lag far behind in other areas of development". It is the case in Libya, where the oil industry has brought exceptional changes to the economy since 1960s when it replaced agriculture as the basis of the economy. Oil is the dominant sector in the Libyan economy, which accounted in 2012 for about $67 \%$ of the total revenues, and more than $90 \%$ of the total exports (CBL, 2013). The non-oil sectors, including agriculture, are suffering from negative productivity growth. For instance, agriculture's share decreased from 48\% in 1957 (Allan, 1973) to less than 1.7\% in 2012 (CBL, 2013). On the other hand, before the advent of oil exploitation in Libya, most of the population engaged productively in activities, such as artisan, fishing, farming, traditional industries, small trading among others. Agricultural growth was related to flourishing rural economy, but the discovery of oil in 1961 created an easier and more profitable forms of employment and thus resulting in a huge migration of workforce from rural to urban areas. The labour ratio in agriculture decreased from about 35.7\% in 1964 to less than 5\% in 2010 (FAO and WEP, 2011).

\section{Research Problem}

Libya, resembles other oil rich Middle East countries in that its economy suffers from socio- economic structural imbalances caused by the dominance of the oil sector over the other economic sectors, negative 
patterns of usage of oil resources and inability to diversify the production base. The heavily depending on oil sector, creates too much income that the governments become less interested in establishing efficient economy, leading to poorly performance of non-oil economies including agriculture sector. Some economic indications refer to the continual decline in the agriculture sector contribution in the economy since 1960s, and the fluctuation growth rates despite the heavy expenditures.

\section{Research objectives:}

- to highlight the agricultural development in the context of oil rich developing countries.

- to build a conceptual framework for agricultural development in Libya as a developing rich oil country.

\section{Data and methods}

The research depended on the data which extracted from literature review; it involves identifying, recording, understanding, meaning-making, and transmitting information, to help researchers building their conceptual framework. The research employed also secondary data to analyze some macroeconomic indications related to the agriculture development. they used descriptive tools, and quantitative statistical analysis methods, in order to investigate the effect of oil revenues on agriculture.

\section{Literature review:}

\subsection{Agricultural development in developing oil rich countries:}

Economic development is the main target of the world's nations, it should increases the real national income of the economies, the per capita, the capital accumulation, and rises the levels of technical efficiency, and the economic productivity for society as a whole. Actually the world's countries have different economic development experiences (Samatar,1999); Grabowski et al. (2007) mentioned to some explanations for this, including differences in human capital, natural resource endowments, population density, degree of openness, market structures, government policies, technology, geography and institutional differences. Agricultural development and economic development are tightly linked (Johnston and Mellor, 1961). It is seen as the first crucial step towards broader development and reduction of poverty and food insecurity (Braun et al., 1994). However agricultural development is one of the components of the comprehensive plan of economic and social development (Alyabis, 2011). However, natural resources, such as gas and oil, should improve economic growth and development. In this context, the supporters of oil-led development believe that oil exporting countries can base their development on this resource, and enhance their socio-economic growth through the creation of jobs, the increased government revenues to finance poverty alleviation, the transfer of technology, the improvement of infrastructure, and the encouragement of related industries (McSherry,2006). In contrast, Karl (2004) opposed the idea of oil-led development and remarked that the experiences of many oil-exporting countries to date have reflected few benefits and too many negative consequences of oil-led development, including slower than expected growth, barriers to economic diversification, poor social welfare indications, and high levels of poverty, inequality, and unemployment. He clarified that resource-poor countries, those without petroleum, grew four times more speedily than the resource-rich countries, those with petroleum, for the period between 1970 and 1993 (Karl, 2007). It is important to mentioned that in the main model of Dutch disease, in developed oil rich countries, the industry sector was positively affected by the oil boom in the 1970s, whereas it contracted the agricultural sector during the boom years in the majority of developing oil-rich countries.

Fardmanesh (1991) provided new methods for developing oil rich economies, expected that developing oil rich countries will face the de-agriculturalization phenomenon instead of de-industrialization that faced the developed oil rich countries after an increase in oil income. Furthermore, Bravo-Ortega and Gregorio (2005) argued that there are too many experiences where the oil sector has been blamed for the underdevelopment or

low growth rates of certain economies; Gylfason (2001) observed that the mere existence of natural resources, does not cause economic recession, rather it abundance induces certain distortions in the economy, which then 
work as transmission mechanisms, which, in turn, affect economic growth and development. Substantial literature explored the existence of the Dutch disease and de-agriculturalization phenomena in many developing oil rich countries. Ahmadi (2014) examined the impact of oil revenue on agriculture value added in the Iranian economy, his results revealed existence of Dutch disease and de-agriculturalization, wherein the long-run coefficient of oil revenue was estimated at -1.42 . Political economic scientists (Ross,2001; Crystal,1990; and Barro,1999) have documented a robust and statistically significant association between oil dependence and authoritarian government in developing world. Oil has appeared to impede the development of democracy in most cases, especially Middle East, Africa, Iran and some Gulf countries, McSherry (2006, p 31) contended that several African oil-producing countries have adopted similar paths; they use the oil revenues to enhance their patronage networks; thus, they suppress opposition. For instance, the leaders of the Democratic Republic of Congo, Gabon and Angola have proved to be capable of reinforcing their despotic rule via patronage politics. By contrast, Omgba (2011) and Ammani (2011) claimed that windfall of oil cannot be held responsible for the fall in the agriculture sector, for instance the oil boom has a positive effect on the traditional non-oil sector in Cameroon; where the Cameroonian government managed the oil revenues efficiently and saved approximately $75 \%$ of the total revenue during the oil boom period of the 1980s. in the same context, Samatar (1999) pointed out that Botswana used its mineral wealth to improve its economy, build infrastructure, develop poor relief programs and construct foreign reserves so as to avoid Dutch Disease.

Oil may create so much income that the governments become less interested in establishing efficient economy. In Nigeria, Budina et al. (2006) concluded that the oil boom has not put an end to poverty or to the perennial stagnation in the non-oil economy including agriculture. They mentioned that debt overhang problems, high public expenditure and institutional inability to reconcile competing claims for oil money are exacerbated by misguided policies and have caused spending levels to exceed the rising oil wealth; these are the main factors behind the failure of agricultural reform. Also, Moradi, et al (2010) and Mehdi (2011) argued that the economic difficulties stemming from the oil boom and its aftermath of economic recession in the Middle East have tended to worsen the endemic political instability in the region; he argued that considerable oil wealth has done little to improve the non-oil sectors, which have receded in relative importance. There was an absolute decline in the levels of agricultural output. Most of the countries that depend heavily on oil eventually become among the most economically troubled, most authoritarian, and most conflict-ridden in the world (LeBillon, 2001). The problem is that the oil revenues corrupt the people in power, who misuse them revenues to serve their own interests. Oil countries need to diversify their economy base, a free market-oriented economy and solid and advanced institutions. The mineral-wealth should be utilized to improve the state economy, shape the infrastructure, and promote relief programs.

\subsection{Agricultural development in Libya:}

The agriculture sector in Libya has undergone various developmental stages that have brought about many economic and political changes. During the 1960s, the government concentrated more on the service and construction sectors, which developed significantly after the oil discovery, however the agriculture sector started to receive significant attention in 1970s. Despite the fact that Libya's agricultural sector was always a main priority for the government during the period after the adoption of socialism, its growth rate still does not reflect the level of government expenditure, and its contribution to the economy is still lower than that of other sectors. 
TABLE I: Agricultural development allocations in different eco political stages in Libya.

\begin{tabular}{|c|c|c|}
\hline Time Period & Description of political economic issues & $\begin{array}{l}\text { \% of Agricultural } \\
\text { development allocations } \\
\text { from total allocation. }\end{array}$ \\
\hline $1963-1975$ & $\begin{array}{l}\text { The beginning of real implications of national development based heavily on oil } \\
\text { revenues, where the focus was on infrastructure, housing construction, roads, health, } \\
\text { educational and service institutions. }\end{array}$ & $11.91 \%$ \\
\hline 1976-1986 & The period of radical implications of socialism, and strong attention given to agriculture. & $17.37 \%$ \\
\hline $1987-2000$ & $\begin{array}{l}\text { The period of the political and economic crisis caused by falling oil prices, then the } \\
\text { economic blockade, opening the way for the private sector to contribute to domestic } \\
\text { investments. The UN imposing of economic sanctions on Libya in } 1992-2000 \text {. }\end{array}$ & $16.17 \%$ \\
\hline $2000-2010$ & $\begin{array}{l}\text { The period of exit from political closure and opening to the outside world, and opening } \\
\text { the doors to foreign investment }\end{array}$ & $7.08 \%$ \\
\hline
\end{tabular}

However table (1) above shows the stages that Libyan economy has undergone (1965-2010), and explain the eco-political main features of each stage and the government expeditions on agricultural plans during these times. According to Esehaib, et al (2018) there is an inverse relationship between the government investment expenditures and the investment efficiency in agriculture sector. The figure (1) below showed some economic indications of agriculture sector, where the total GDP increases in the same flow of oil revenues, however agriculture GDP remain low in most of years. On the other hand, levels of agricultural production, including those for cereals, vegetables, fruits, livestock and fish and dairy production are very low compared to the neighbouring countries (Abuarosha, 2013). The agriculture sector exhibited fluctuating growth rates in the period (1970-2010), whereas performance was better in the period from the late 1970s to the early 1990s (Alrainy,2001), however agriculture's contribution to GDP has increased since 1980, when the oil revenues started to decline. Bruce (2008) observed that since the mid of the 1980s, Libya has witnessed a gradual increase in agricultural growth. Although the agricultural contribution to non-oil GDP was higher than its contribution to GDP including the oil sector, it was still lower than the expected levels based on the heavy investment. On the other hand agricultural sector cannot support itself in economic terms, where oil is the core fund resources of its operations and development plans.

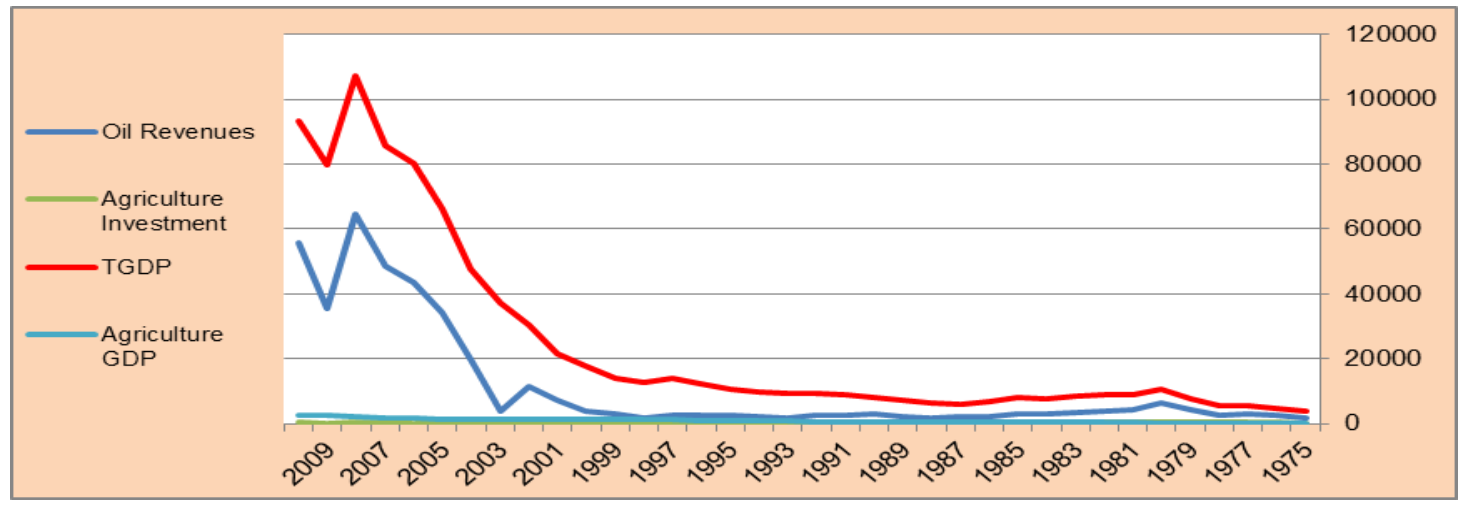

Fig. 1: Some economic indications of Libyan economy

In regarding to the obstacles facing agriculture Larbah (1996) mentioned to the scarcity of water resources and arid climatic conditions; however, apart from the ecological difficulties, there are other significant problems facing the development of the agricultural sector, These problems have been reported by substantial literature review, such as Aljady (2005); Etlopa (2007); Abidar and Lytimi (2005); Alsaeh (2004); and Abuarosha (2013) Khalifa (2006) ; it include, for instance, major dependence on foreign labour, lack of training programs, mismanagement, corrupted administrative procedures, lack of monitoring system, unstable agricultural institutional structures; and lack of information systems. In addition, weak financing system and weak agricultural infrastructure. The review of the literature mentioned to increasingly large role of public sector in 
the large scale agricultural projects, resulting lack of effective monitoring and the spread of corruption among the ruling elite as key issues, the key driver being the personal interests of the ruling elite and their supporters. Also public sector monopolised marketing activities and limited the role of the private commercial sector .This in turn has led to increasing mismanagement of agricultural resources by key decision-makers at the expense of efficiency. Thus the move towards more private sector involvement, has in practice not happened because it contradicted the particular interests of those key decision-makers in the public sector (Porter, 2006).

\section{Analysis of some macroeconomic indications of agricultural sector in Libya:}

Table (2) below shows some the mean of economic statistics of the Libyan economy during the period from 1963 to 2010. These include the oil revenues, total government investments, agricultural investment, GDP and agricultural GDP, in addition to the relative importance of government investment expenditure on the agricultural sector of total investments. The growth rate of the agricultural sector and its contribution to GDP.

TABLE II: Economic indicators of agriculture sector in Libya

\begin{tabular}{cllllllll}
\hline \hline Time series & $\begin{array}{l}\text { Oil } \\
\text { revenues }\end{array}$ & $\begin{array}{l}\text { Total } \\
\text { investment }\end{array}$ & $\begin{array}{l}\text { Agriculture } \\
\text { investment }\end{array}$ & $\begin{array}{l}\text { Total } \\
\text { GDP }\end{array}$ & $\begin{array}{l}\text { Agricultur } \\
\text { e GDP }\end{array}$ & $\begin{array}{l}\text { Growth } \\
\text { rate }\end{array}$ & $\begin{array}{l}\text { Agriculture } \\
\text { Contribution }\end{array}$ & $\begin{array}{l}\text { Oil } \\
\text { contribution }\end{array}$ \\
\hline \hline $1963-1975$ & 972.13 & 319.03 & 63.38 & 1677.33 & 42.86 & 14.15 & 3.11 & 58.08 \\
$1976-2086$ & 3560.27 & 1824.42 & 301.52 & 7537.75 & 264.75 & 15.21 & 3.08 & 47.47 \\
$1987-2000$ & 2417.60 & 693.96 & 109.71 & 10395.06 & 858.91 & 9.31 & 7.94 & 24.39 \\
$2001-2010$ & 33470.57 & 4037.17 & 236.65 & 64944.17 & 1761.47 & 6.48 & 3.61 & 64.01 \\
\hline \hline
\end{tabular}

Resource: calculated by researches based on time series of the indications published by General Plan Council(2003), Central Bank of Libya (2012).

By analyzing the relationship between agricultural GDP as a dependent variable and agricultural investment as an independent variable, the significance of the relationship between them has not been established at the usual significant levels $(5 \%, 1 \%)$. However analysis of the relationship between the investment expenditure on the agricultural sector (Y), and the money inflows coming from oil revenues (X) using the (OLS) methods; the results of the two equations presented in table (3) indicated that the oil revenues had a statistically significant effect at the level of $1 \%$ on agricultural investment expenditure during the study periods (1963-1985) (19862010) with $\mathrm{R}^{2} 92 \%, 51 \%$ for the first, and second periods respectively. The statistical analysis showed that the impact of oil revenues was more pronounced during the initial period, which can be attributed to the rapid economic and political changes and fluctuations experienced by the oil market, and had a great impact on the instability of oil revenues, and introduced prices marked in this period increased, which reflected on the trend of government investments which invested heavily in all economic, social and infrastructure sectors. The second period reflected a less robust relationship between oil revenues and government investment spending on the agricultural sector. This may be attributed to the change in state policies towards the agricultural sector or the ways in which it exploits oil revenue.

TABLE III: Economic indicators of agriculture sector in Libya

\begin{tabular}{llcccc}
\hline \hline Time period & Model equation & & F & $\mathrm{R}^{2}$ & $\mathrm{DW}$ \\
\hline $1963-1985$ & $Y=-20.545+0.091 X$ & $(15.62)^{* *}$ & 243.94 & 0.92 & 1.66 \\
$1986-2010$ & $Y=104.053+0.004 X$ & $(4.80)^{* *}$ & 223.003 & 0.51 & 1.97 \\
\hline
\end{tabular}

** The model at the level of significance $1 \%$ and the models free of the problem of self-correlation for the first and second period while the problem appeared to the total period and addressed by the difference.

\section{The conceptual framework for agricultural development issues in Libya:}

Based on the preceding argument in the literature review and the economic indications of agriculture sector, the researchers developed a conceptual framework that identified the key issues of the agricultural development process in Libya, bearing in mind that ecological factors have included as a sub-driver of agricultural development in this framework. The lack of arable land, the unfavourable climatic conditions and scarcity of water have hindered the development of the agriculture sector, primarily in cultivation and animal husbandry, 
while wild fishery and fish farming are less affected by these limitations. However, the literature review demonstrated that despite the similarity in ecological conditions among the MNA countries, it seems that their agricultural performances differ; while Egypt has the best performance, Libya has the worst according to the agricultural GDP, and its contribution to the national economy (Abuarosha, 2013) and (ADAO, 2014). The conceptual framework below (Figure 2) presents the key drivers and impediments to Libya's agriculture development. The key drivers are based on two main propositions, that were extracted from the literature review; 1) The availability of oil as a non-renewable source of revenue and the ways of exploiting it, economically and politically, 2) The adoption of a large number of economic planning criteria, the main one being public sector domination of the state's establishment.

As is evident from the literature review, Libya is a rich oil country, a socialist state to a great extent, and it has been ruled for more than four decades by a non-classical regime called Jamahiriya, headed by a leader with uncommon political ideologies (Vandewalle, 2011, 2006 )(Edwik, 2007). For instant the Self-sufficiency, as an agricultural policy, was mainly inspired by a statement found in Green Book, said: "no freedom for a nation brings food from across the sea" (Qaddafi 1977). This statement, in particular, expressed the interest of the ruler in the policy of food full self-sufficiency, Though this ideology seems impressive, the fact, is that Libya cannot be fully self-sufficient. This ideology is thus rendered unattainable and creates a drain on national resources. On the other hand, when the agriculture sector failed to meet the country's food needs, oil revenues facilitated the process of obtaining imported food, with more than $90 \%$ of food necessities now imported from abroad and funded by the oil revenues (CBL, 2013). Here again oil is playing a critical role in covering of the agriculture sector's shortcomings in terms of food provision.

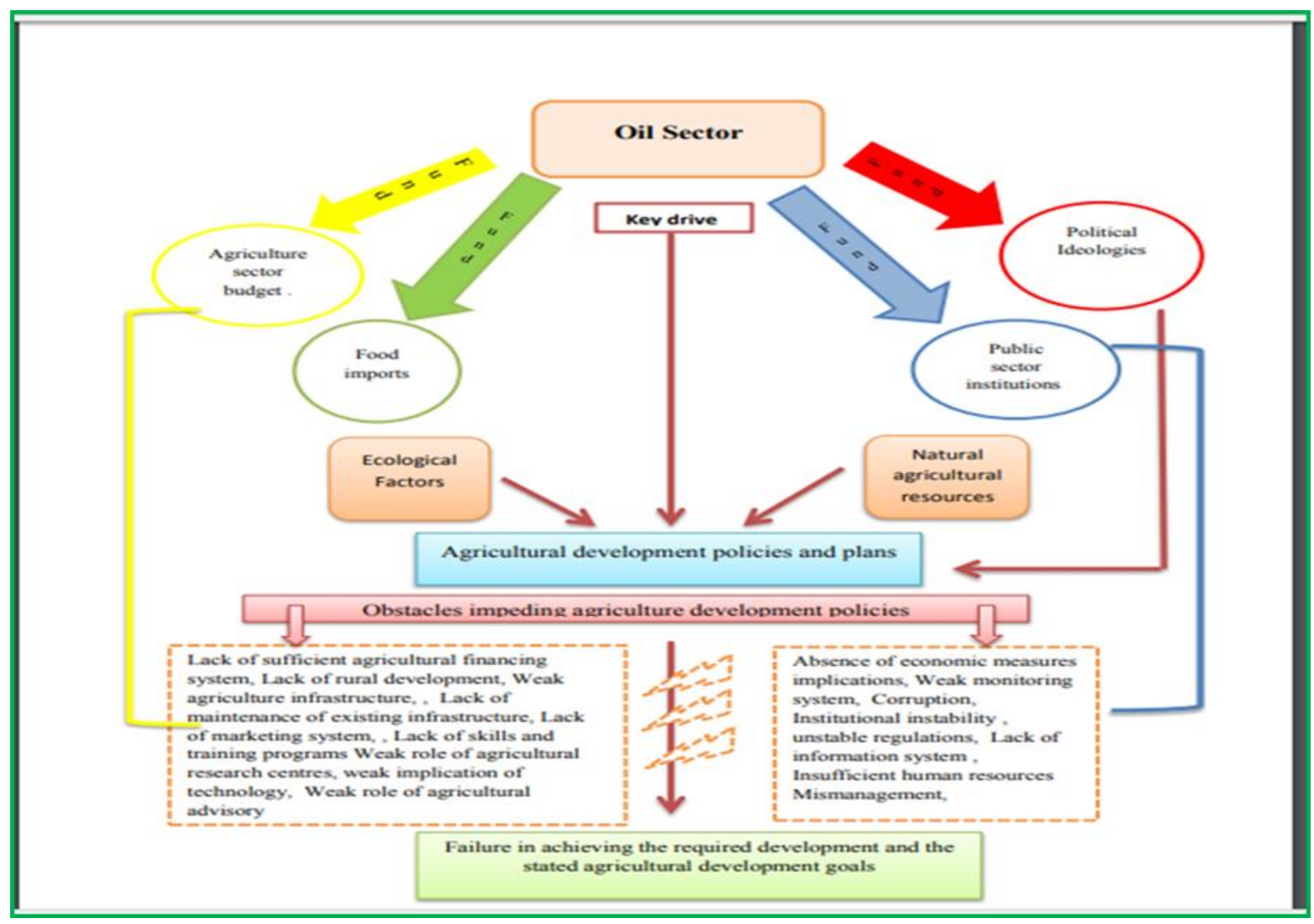

Fig. 2: Conceptual framework of agriculture development in Libya as an oil rich country

The framework also raise the idea of that the agriculture sector, has been affected by the dominant role of the public sector. Actually, the implementation of a planned economy since the 1970s has given the public sector institutions priority in taking over and administering strategic agricultural enterprises. However, despite the fact 
that there are a considerable number of small-scale projects, operated, but not owned, by Libyan citizens, these are not recognized in the economy, like other public administered projects which are supported heavily by the government. Under the public sector's ownership and management of large scale and strategic agricultural projects it seems that little attention has been paid to their profitability and efficiency. Moreover, the corruption that exists among public sector authorities has made the situation even more problematic. The dominant role of public sector was driven by political ideologies, were its influence on the agriculture sector is not limited to the adoption of self-sufficiency ideologies; it extends to the means of managing the sector. An example of political leadership thoughts is that "the private sector is an exploiter of the people's needs", and " the land belongs to noone". Such thoughts were translated into government legislation and procedures. They transferred most of the power to the public sector, and despite the latest reforms in the economy in this regard, the public sector still has a great influence.

The framework also defines the main problems and obstacles hindering agricultural development.(see figure 2 ) above. Some of related the weak public sector such as absence of economic measures implications, weak monitoring system, corruption, and mismanagement. Other problems related to the agriculture implications

such as, lack of rural development, weak agriculture infrastructure, , Lack of skilled workers weak role of agricultural advisory, these problems among other were presented in the conceptual framework.

\section{References}

[1] M. Lotfalipour, R., S. Ahmadi, T," Investigation influencing mechanisms and short term - long term dynamism impact of Iran's oil revenues on value added in agriculture". Asian Research Consortium, vol 4(10), pp184-193. 2014.

https://doi.org/10.5958/2249-7307.2014.00958.X

[2] L. Omgba,D, "Oil wealth and non-oil sector performance in a developing country: Evidence from Cameroon". Oxford Development Studies, 39(4), 487-503, February 2011.

https://doi.org/10.1080/13600818.2011.620088

[3] M. Moradi, M. Salehi, M. Keivanfar, "A study of the effect of oil price fluctuation on industrial and agricultural products in Iran". Asian Journal on Quality, vol 11(3), pp 303-316., March 2010.

https://doi.org/10.1108/15982681011094041

[4] L. Karl,T., Social and political consequences of oil. Encyclopedia of energy, (2004). 4, 661-672.

[5] L. Karl, T., "Oil-led development: social, political, and economic consequences". Spogli Institute for International Studies; No: 80 , (2007). Stanford University

[6] A. Samatar, I., State and class leadership and colonial legacy in Botswana development.1999, Heinemann Portsmouth.

[7] P. Lebillon., "Natural resources and armed conflict." political geography 20 (5), 561-584. (2001). https://doi.org/10.1016/S0962-6298(01)00015-4

[8] B. Johnston, F. and J. Mellor W.,. the role of agriculture in economic development. American Economic Review, 51(4), 566-593.(1961)

[9] E. Al-Seah. "Agricultural investment in Libyan economy (1985-2002)". Presented in Conference of Encouraging the Local Investment in Libya (the Potential and the Targets). (2004). Tripoli, University of Tripoli

[10] A. Aljady. "Agriculture marketing in Libya: policies and facts" Presented in Sciences Conference of Agricultural Production. (2005). University of Tripoli Publication.

[11] A. Abidar, and A. Laytimi. National agriculture policy in Libya. [online] MEDFROL Project. Sixth framework program priority 8.1. report from Integrating and Strengthening the European Research Area. (2005).

[12] T. Gylfason,. "Natural resources and economic development". European Economic Review, 45(4-6) 847-859. (2001) https://doi.org/10.1016/S0014-2921(01)00127-1 
[13] J. Crystal. Oil and politics in the gulf: rulers and merchants in Kuwait. Cambridge: Cambridge university press(1990). https://doi.org/10.1017/CBO9780511558818

[14] R. Barro, r. J. "Determinants of democracy. journal of political economy", 107 (6) 158-s183. (1999) https://doi.org/10.1086/250107

[15]C. Bravo-Ortega, c., and J. Gregorio, D. The relative richness of the poor? natural resources, human capital and economic growth. world bank. no: 3484,(2005)

https://doi.org/10.1596/1813-9450-3484

[16] N. Budina,. G, Bang, S. Wijnbergen, Nigeria: Dutch disease or debt overhang?. [on line]. world bank. (2006).

[17]R. Bruce, S., "The changing Libyan economy: causes and consequences". Middle East Journal, Vol. 62(1),pp76-92. June 2008.

https://doi.org/10.3751/62.1.14

[18] H. Al-rainy. Agriculture sector contribution in the gross domestic product in Libya. M.S. Dept., Economic. Academy of Graduate Studies(2001).

[19] J. Allan, A., K. Mclachlan, s. and E. Penrose, T., Libya: Agriculture and Economic Development. London, frank Cass and Oregon. 1973.

[20] A. Ammani, A., "Nigeria's oil boom period (1973-1983): Was agriculture really neglected?" International Journal of Statistics and Research, Vol 1(1), 6-9, July 2011.

https://doi.org/10.5923/j.statistics.20110101.02

[21] M. Fardmanesh, "Dutch disease economics and oil syndrome: An empirical study". WD Vol 19(6),pp 711-717. (1991), https://doi.org/10.1016/0305-750X(91)90205-V

[22] S. Mehdi, M. Reza," A study examining the effect of oil exports on agricultural value added in Iran". Journal of Education and Vocational Research, vol 2(1), pp10-17. (2011), https://doi.org/10.22610/jevr.v2i1.19

[23] A. Edwik ,A., Oil dependency, economic development: a case study of Libya. PhD, University of Salford.2007.

[24]D. Vandewalle, A history of modern Libya. London, Cambridge University Press, Tauris and Co Ltd. 2006. https://doi.org/10.1017/CBO9780511986246

[25] D. Vandewalle, Libya since 1969: Qaddafi's Revolution Revisited. London, Cambridge University Press, 2011.

[26] M, Porter, E., and D. Chairman, Y, "National economic strategy: an assessment of the competitiveness of the Libyan Arab Jamahiriya". Libya. Monitor Group, Report for General planning Council, Libya. (2006).

[27]FAO, And WFP, "Food Security in Libya: An Overview Report". Italy. Food and Agriculture Organization,. 20111.

[28] CBL , Annual Report, Tripoli, 2013.

[29] GCP, The Allocation and Expenders on agriculture sector, Yearly statistics, Tripoli, Libya, 2009. 